\title{
Extent of infection by Viscum album L. and changes in its occurrence on ornamental woody species in the locality of Lednice (Czech Republic)
}

\author{
Pavel Bulír \\ Faculty of Horticulture in Lednice \\ Mendel University in Brno \\ Valtická 337, 69144 Lednice, Czech Republic
}

\begin{abstract}
The main goal of the research conducted in the Lednice chateau park was to map the current spectrum of host trees and shrubs. The aim of the investigation was also to record changes in the host species, namely between the years 1985 and 2016, and to get an overview of the extent and degree of mistletoe infection on the most significant tree species present in the park. Furthermore, the occurrence of mistletoe across the developmental stages of woody species was monitored. Apart from taxonomic changes also the quantitative extent and the degree of infection reported in the last 31 years, and the impact on the development stages of woody plants in the past 20 years were analysed. Among the most frequently infected taxa are currently: Acer campestre, Acer platanoides, Acer pseudoplatanus, Crataegus monogyna, Robinia pseudoacacia, Tilia cordata and Tilia platyphyllos. The average share of infected specimens of the above host species amounts to $34.28 \%$. A distinctive change in frequency and infection degree was recorded in the aggregate spectrum of hosts. The presence of mistletoe was recorded in a total of 1,362 specimens (almost $12 \%$ of the trees growing in the area). Compared to 1985, the occurrence of mistletoe was newly recorded in a total of 13 families $(+3)$, 19 genera (+5) and 42 species (+18). In Aesculus xmarylandica, Fraxinus biltmoreana, Magnolia hypoleuca $\times$ tripetala or Malus $\times$ moerlandsii, it was probably described for the first time ever. At the moment, the most existentially endangered taxon is Tilia cordata.
\end{abstract}

Key words: European mistletoe, host structure change, host woody species, infection intensity

\section{INTRODUCTION}

Today, the extensive genus Viscum is systematically classified in the Santalales order and in the Santalaceae family (Der and Nickrent 2008, Nickrent et al. 2010). The European mistletoe (Viscum album L.) is a native hemiparasitic shrub, spread widely yet locally in many places of Europe and Asia (Hegi 1981, Luther and Becker 1987, Slavík 1997, Zuber 2004, Rist et al. 2011, Kołodziejek et al. 2013, Varga et. al 2014). In the Czech Republic, its occurrence is largely uneven (Procházka 2004). Within this species, a total of four subspecies have been described (Ball 1993, Böhling et al. 2002, Barbu 2010), three of which can be found in the Czech Republic (Koblížek 2000, Kubát et al. 2002). By far the most widespread native subspecies, occurring at the same time on the largest number of host trees and shrubs, and having the largest impact on their quality, is Viscum album L. subsp. album P.W. BALL. In numerous localities 
with high density of its natural occurrence, this mistletoe is a preeminent pathogenic factor, and hence also a subject of research (Hawksworth et al. 1991, Butin 1995, Mathiasen et al. 2008). With its parasitic activities, it causes much damage to the host trees and shrubs, not only economic damage, e.g. in forestry (Tsopelas et al. 2004), but also socio-cultural, aesthetical and cultivation damage, e.g. in landscape architecture (Spálavský 2001, Zachwatowicz et al. 2008, Eliáš 2010, Huber 2011). The frequency or extent of occurrence of this mistletoe, as well as the study of the spectrum of its host woody species have been the subject of many scientific papers and comprehensive studies (Wangerin 1937, Stopp 1961, Barney et al. 1998). Much of this research has been carried out mainly in urban environments and in gardens and parks (Unar 1985, Procházka 2004, Święs 2008, Zachwatowicz et al. 2008, Kołodziejek et al. 2013), which contained both autochthonous and allochthonous woody plants. Long-term and often expansive and aggressive infection of a host plant by mistletoe leads to damage of its above-ground architecture. It causes a gradual physiological weakening of the infected trees and shrubs, leads to signs of premature senescence, but above all it leads to an increased sensitivity of the infected trees and shrubs to other pathological agents (Mathiasen et al. 2008). The lifespan of infected trees is significantly shortened. Also the usable potential, based on the biological and aesthetical condition of the tree or shrub concerned, and on its spatial and age structure, tends to be low in the case of infected specimens. The spectrum of host trees and shrubs is different in individual localities. Similarly, the examined habitats differ, as probably do the consequences of long-term impact of mistletoe on the qualitative parameters of their hosts. In this respect, there is still lack of sound information on the actual spectrum, extent and degree of infection of individual host trees and shrubs in the context of a longer chronological development. Therefore, the aim of our investigation was to analyse these fundamental facts. At the same time, the impact on the development stages (DS) of woody plants was monitored and evaluated. The knowledge acquired can be a valuable source of information which can help improve landscape management not only on this world heritage site but also in many other historical parks with mistletoe occurrence. It can lead to more effective methods of tree growing and maintenance, or help modify the way in which trees are pruned. During ongoing restoration of historical garden monuments in places with high mistletoe occurrence, this information can also serve as a basis for choosing the right tree species for new plantings.

\section{MATERIAL AND METHODS}

The research locality of Lednice (Fig. 1) is situated in South Moravia, in the area of thermophyticum,

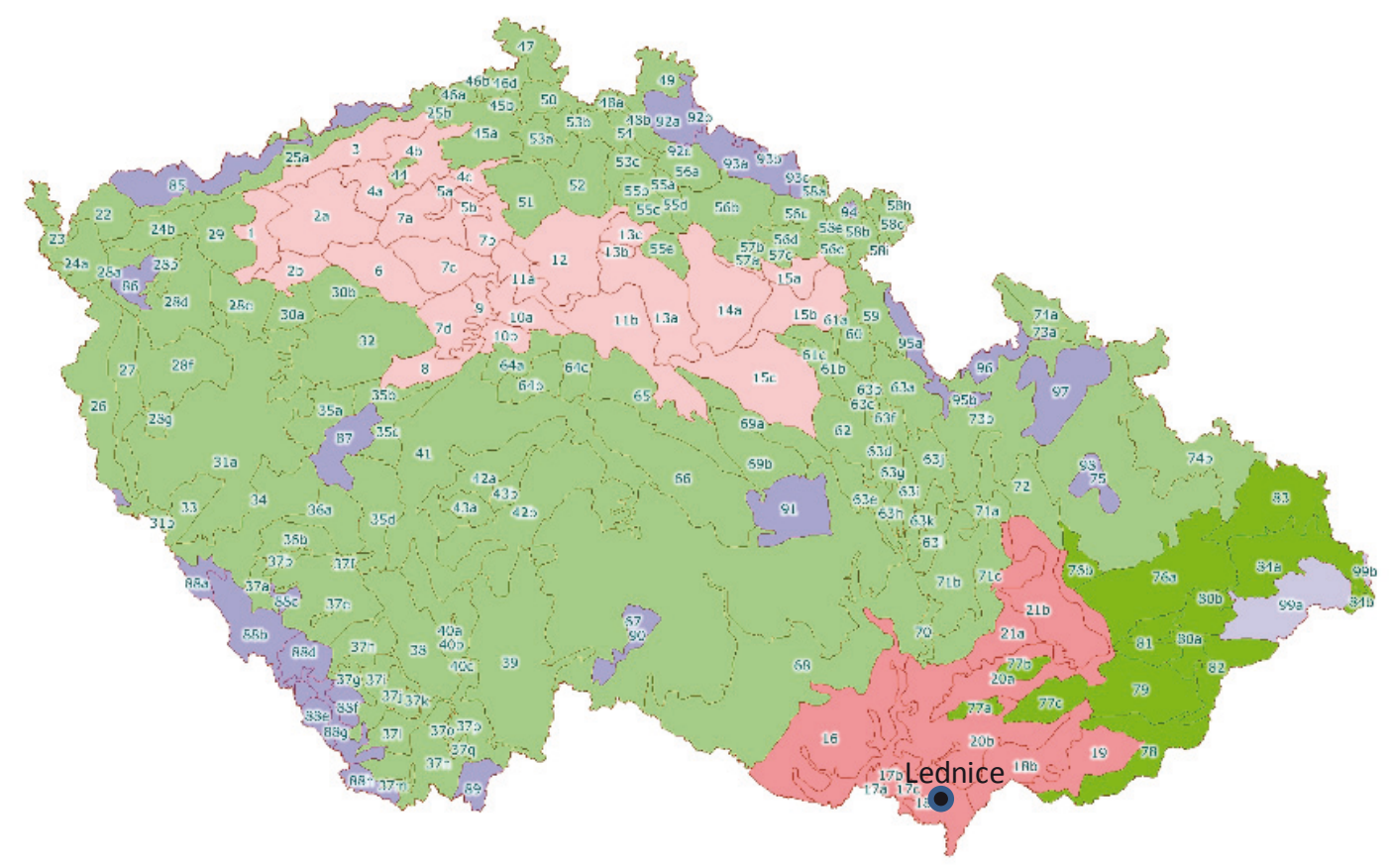

Figure 1. The research locality of Lednice is situated in South Moravia, in the area of Pannonian thermophyticum (Slavík 1988) 
in the 18a phytogeographic sub-district - Dyjskosvratecký úval (Skalický 1988, Slavík 1988).

With respect to the targets of our investigation, the locality in question was narrowed to a field research area of 170 ha covering the chateau parkland and its closest surroundings. The whole administrative cadastral area of Lednice (31.2 $\mathrm{km}^{2}$ ) was considered only for comparing the development of the spectrum of host trees and shrubs over time. The selected locality is part of Lednice-Valtice Cultural Landscape entered on the UNESCO World Heritage List. In this locality, there is probably the highest density of the European Mistletoe occurrence and also the greatest number of potential host species in the Czech Republic (Procházka 2004). The locality is situated at an altitude of 165-176 m above sea level. According to Quitt's climate classification (Culek 1996), the whole territory belongs to the warmest area of the Czech Republic labelled as T4. The mean annual temperature is $9^{\circ} \mathrm{C}$ and the mean precipitation amount ranges between $300-350 \mathrm{~mm}$ during the vegetation period and $200-300 \mathrm{~mm}$ in winter. The potential natural vegetation in this locality is formed mainly by bottomland hardwood forests of the suballiance Ulmenion represented in particular by the associations Ficario-Ulmetum campestris and Fraxino pannonicae-Ulmetum, which change into associations of the type PrimuloverisCarpinetum in the highest places of the alluvium and on anthropogenic soils (Culek 1996). The field research was carried out on the whole present spectrum of tree species in the 2012-2016 period, mainly in winter time. Two attributes were simultaneously recorded: mistletoe occurrence and tree development stage. For the subsequent detailed evaluation, only seven important tree species were selected. These are currently the most frequent host species and at the same time the trees that form the main vegetation structure of the park. In order to evaluate mistletoe occurrence, on a selected sample of trees and shrubs in the given locality, we assessed the percentage of the overall active assimilation volume of the crown of the host tree or shrub against the proportion of the volume of parasitizing mistletoe. For mistletoe occurrence evaluation, we used a four-degree rating system: 0 degree: no occurrence - no signs of mistletoe infection were found on the evaluated tree or shrub; $1^{s t}$ degree: insignificant occurrence - assimilation mass of the host plant clearly prevails on the evaluated tree or shrub. The specimen is usually infected unevenly or in clusters with mistletoe shrubs forming up to
$30 \%$ of the total volume of the crown of the host tree or shrub; $2^{\text {nd }}$ degree: significant occurrence - the evaluated tree or shrub is infected to a significant extent, either evenly or in clusters. Its physiological vitality is visibly decreased. Mistletoe shrubs form $30-60 \%$ of the active assimilation volume of the crown of the host tree or shrub; $3^{\text {rd }}$ degree: critical occurrence - assimilation mass of mistletoe exceeds the mass of the assimilation apparatus of the host tree or shrub. Mistletoe shrubs form more than $60 \%$ of the total volume of the crown of the host tree or shrub. The infected plant is visibly wilting. For development stage (DS) evaluation, we used the following codes: DS 1 - newly planted/germinating specimen, DS 2 - rooted specimen, DS 3 - stabilized maturing specimen, DS 4 - mature specimen, DS 5 - superannuated specimen. The recorded development stage data (DS) for the most important host trees and shrubs were then compared with available values (Pejchal and Šimek 1996). The occurrence of mistletoe or its extent was evaluated in relation to the records published by Unar (1985) and Spálavský (2001). The nomenclature used is in accordance with the publication by Roloff and Bärtels (2006). The value for the frequency of occurrence, expressed as an absolute or equivalent percentage value, was selected for processing and evaluating the data. The data were ordered and analysed according to the key quantitative and qualitative features using contingency tables processed in MS Excel for the seven most important host taxa. For the purposes of this evaluation, the constant feature was mistletoe occurrence (degrees 0-3). The variable attributes analysed individual development stages (DS) in 1996 and in 2016. In the following steps, the level of infection probability of a plant of a particular taxon was analysed. The probability was expressed in $\%$. The sum of specimens of a given taxon was thus compared with the relevant number of infected taxa. These values were then adjusted by the qualitative attributes of the development stages; for these values, the structure of infection probability was also established.

\section{RESULTS AND DISCUSSION}

The spectrum of host trees and shrubs, and the distribution of mistletoe in the locality of Lednice were recorded by many authors in the past (Houfek 1973, Unar et al. 1985, Spálavský 2001, Bulíř 2010). Indirectly, possibly among other damage, its occurrence was also partly monitored in connection with the evaluation of the dendrological 
potential of the local chateau park (Pejchal and Šimek 1996). However, from among the sources mentioned, only Unar et al. (1985) and Spálavský (2001) provide quantitatively, qualitatively and, in particular, territorially comparable data. Based on the experiment conducted and on its results, a summary table was compiled (Tab. 1), providing an overview of the present-day spectrum of host trees and shrubs as well as the extent of their infection over time, namely between 1985 and 2016. The results clearly show a sharp increase in the number of host taxa. Thirty-one years ago, Unar et al. (1985) reported within the chateau park a total of 24 infected woody species belonging to 14 genera and 10 families. In the whole cadastral area of Lednice $\left(31.2 \mathrm{~km}^{2}\right)$, there were 36 host woody species belonging to 15 genera and 11 families. The results of this investigation, carried out between 2012 and 2016, described 42 host woody species belonging to 19 genera and 13 families within the chateau park alone. Data published in 2001 (Spálavský 2001) suggest an even broader spectrum of host woody species, since they were collected before some hazardous individuals were felled in the last five years. The number of host taxa varies over time and is thus subject to change. In the selected time period (between 1985 and 2016), the occurrence of mistletoe was observed in a total of 17 families, 30 genera and 87 species. In the context of the data available so far for the whole Czech Republic (Houfek 1973, Procházka 2004) this positively confirms the quantitative primacy of the locality. Among the reported host trees and shrubs there are also Aesculus ×marylandica, Fraxinus biltmoreana, Magnolia hypoleuca ×tripetala and Malus ×moerlandsii, which are species not included in the comprehensive list of 452 hosts of mistletoe recorded primarily in Europe and Asia by Barney et al. (1998). This also confirms the fact that mistletoe responds even to partial changes in the environmental conditions. These changes and long-term landscape management (particularly the technology of tree maintenance) probably also influence its preferences for a certain group of host plants in time and space. Striking is also the apparent change in the frequency of infection of individual host taxa as well as other observed changes of predominantly quantitative nature. According to the records published by Unar et al. (1985), 31 years ago there was no mistletoe occurrence in the chateau park on Acer campestre (and only sporadically outside the park), on Crataegus monogyna and Tilia platyphyllos (frequently outside the park). However, according to the results of our investigation, all of the above taxa belong today to much infected species. The probability of colonisation of every specimen growing in the chateau park presently amounts to $29.87 \%$ for Acer campestre, $38.78 \%$ for Crataegus monogyna and $38.48 \%$ for Tilia platyphyllos (Tab. 2). Moreover, the above species are presently among the seven most significant host woody species (the remaining in this locality are Acer platanoides, Acer pseudoplatanus, Robinia pseudoacacia and Tilia cordata). Similarly, the intensity and extent of infection increased also in other species described in all the compared researches (Tab. 1), e.g. Tilia cordata or Carpinus betulus. An opposite trend can be observed in the representatives of the Malus, Salix and Populus genera, where the extent of infection has decreased compared to 31 years ago. In particular, this might be caused by several jointly acting factors. In the first place, these taxa generally have shorter lives and their lifespan has been further reduced by the pathogenic activities of mistletoe. The existing populations of these trees have been significantly reduced also by the activities of the European beaver (Castor fiber). Finally, irrecoverably damaged trees were removed without adequate taxonomic replacement in the context of the renewal measures that are continuously performed in the park. In other host trees and shrubs, where the occurrence of mistletoe was detected in 1985 (Unar et al. 1985), such as Acer negundo, Aesculus hippocastanum, Fraxinus americana, Fraxinus angustifolia and Loranthus europaeus, later researches did not find mistletoe at all or only rarely (Spálavský 2001), although in the course of time the overall number of specimens of these taxa has changed rather insignificantly. This phenomenon might be explained by the fact that mistletoe continuously specialises in a certain group of preferred host trees and shrubs, a process that is also influenced by changing environmental conditions. According to the overview mentioned, basically a constant change in the extent and degree of infection over time has been recorded in, among others, Acer platanoides, Acer pseudoplatanus, Celtis occidentalis and Juglans nigra - taxa which are infected relatively frequently, even extensively.

For the most numerous host species as well as for the species forming the vegetation framework of the chateau park, a separate detailed overview has been drawn up (Tab. 2), presenting the level of probability and showing the extent and degree of their infection. The share of infected specimens in 
Table 1. Overview of mistletoe occurrence in the locality of Lednice between 1985 and 2016

\begin{tabular}{|c|c|c|c|c|c|c|c|c|c|}
\hline \multirow[b]{2}{*}{ 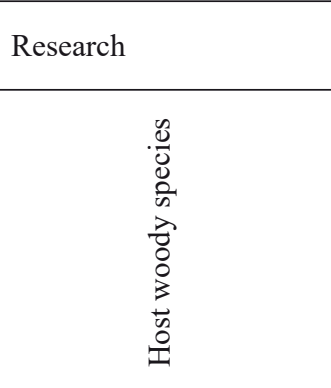 } & \multirow[b]{2}{*}{ 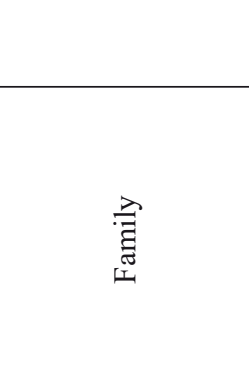 } & \multicolumn{3}{|c|}{$\begin{array}{c}\text { Bulír }(2016) \\
- \text { this experiment }{ }^{1}\end{array}$} & \multicolumn{3}{|c|}{ Spálavský $(2001)^{2}$} & \multicolumn{2}{|c|}{ Unar et al. $(1985)^{2}$} \\
\hline & & 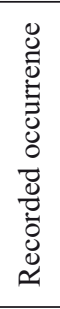 & 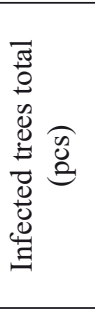 & 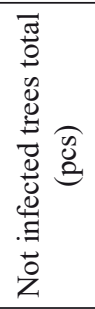 & 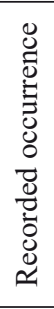 & 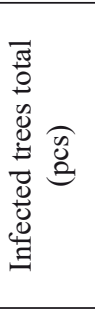 & 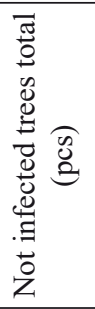 & 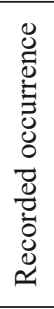 & 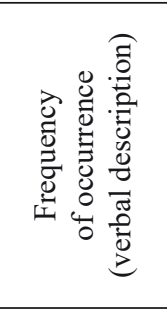 \\
\hline Acer campestre & Aceraceae & 1 & 362 & 850 & 1 & 377 & 976 & $/ *$ & sporadic \\
\hline Acer ginnala & Aceraceae & & & & l & 2 & 21 & & \\
\hline Acer monspessulanum & Aceraceae & & & & l & 1 & 6 & & \\
\hline Acer negundo & Aceraceae & & & & & & & / & fairly often \\
\hline Acer nigrum & Aceraceae & l & 1 & 0 & l & 1 & 0 & & \\
\hline Acer platanoides & Aceraceae & l & 65 & 94 & l & 72 & 116 & l & often \\
\hline Acer pseudoplatanus & Aceraceae & l & 62 & 128 & l & 69 & 142 & l & fairly often \\
\hline Acer rubrum & Aceraceae & l & 2 & 2 & l & 3 & 3 & & \\
\hline Acer saccharinum & Aceraceae & l & 4 & 3 & l & 4 & 4 & l & not seldom \\
\hline Acer saccharum & Aceraceae & / & 11 & 5 & l & 14 & 3 & / & strong \\
\hline Acer tataricum & Aceraceae & & & & l & 1 & 3 & $/ *$ & sporadic \\
\hline Aesculus hippocastanum & Hippocastanaceae & & & & l & 1 & 207 & $/ *$ & sporadic \\
\hline Aesculus flava & Hippocastanaceae & & & & l & 1 & 1 & & \\
\hline Aesculus $\times$ marylandica & Hippocastanaceae & l & 2 & 0 & l & 1 & 1 & & \\
\hline Alnus glutinosa & Betulaceae & l & 38 & 133 & l & 2 & 216 & l & seldom \\
\hline Amelanchier lamarckii & Rosaceae & & & & l & 1 & 1 & & \\
\hline Betula pendula & Betulaceae & / & 10 & 75 & / & 5 & 96 & / & seldom \\
\hline Betula pubescens & Betulaceae & l & 1 & 2 & l & 1 & 4 & & \\
\hline Caragana arborescens & Fabaceae & & & & l & 1 & 4 & & \\
\hline Carpinus betulus & Betulaceae & l & 53 & 255 & l & 18 & 39 & l & very seldom \\
\hline Celtis occidentalis & Ulmaceae & l & 20 & 23 & l & 20 & 22 & l & often \\
\hline Crataegus chrysocarpa & Rosaceae & & & & l & 1 & 2 & l & seldom \\
\hline Crataegus laevigata & Rosaceae & & & & l & 3 & 36 & & \\
\hline Crataegus $\times$ lavallei & Rosaceae & & & & l & 2 & 2 & & \\
\hline Crataegus macrocarpa & Rosaceae & & & & & & & / & often \\
\hline Crataegus monogyna & Rosaceae & l & 38 & 60 & l & 71 & 154 & & \\
\hline Crataegus pedicellata & Rosaceae & l & 34 & 52 & l & 44 & 107 & & \\
\hline Crataegus persimilis & Rosaceae & & & & / & 3 & 4 & & \\
\hline Corylus avellana & Betulaceae & & & & l & 8 & 157 & & \\
\hline Corylus chinensis & Betulaceae & & & & l & 1 & 3 & & \\
\hline Euodia daniellii & Rutaceae & & & & / & 2 & 1 & & \\
\hline Fraxinus americana & Oleaceae & & & & / & 2 & 2 & 1 & fairly strong \\
\hline Fraxinus angustifolia & Oleaceae & & & & l & 1 & 188 & $/ *$ & fairly often \\
\hline Fraxinus biltmoreana & Oleaceae & l & 1 & 1 & l & 1 & 1 & & \\
\hline Fraxinus excelsior & Oleaceae & l & 43 & 154 & / & 23 & 219 & & \\
\hline Fraxinus pensylvanica & Oleaceae & / & 9 & 11 & l & 10 & 17 & & \\
\hline Fraxinus tomentosa & Oleaceae & & & & & & & l & fairly strong \\
\hline Juglans ailantifolia & Juglandaceae & l & 2 & 1 & l & 3 & 0 & & \\
\hline Juglans cinerea & Juglandaceae & l & 1 & 0 & l & 1 & 0 & & \\
\hline Juglans mandshurica & Juglandaceae & 1 & 1 & 0 & 1 & 1 & 0 & & \\
\hline
\end{tabular}


Table 1 continued.

\begin{tabular}{|c|c|c|c|c|c|c|c|c|c|}
\hline \multirow{2}{*}{ 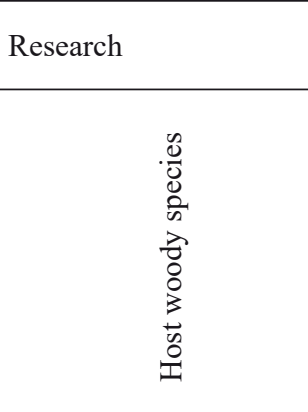 } & \multirow[b]{2}{*}{ 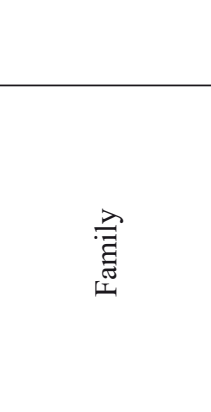 } & \multicolumn{3}{|c|}{$\begin{array}{c}\text { Bulír }_{(2016)} \\
- \text { this experiment }^{1}\end{array}$} & \multicolumn{3}{|c|}{ Spálavský (2001) ${ }^{2}$} & \multicolumn{2}{|c|}{ Unar et al. (1985) ${ }^{2}$} \\
\hline & & 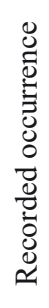 & 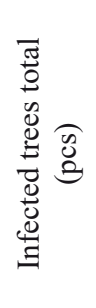 & 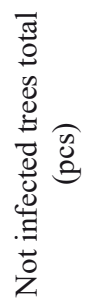 & 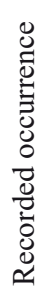 & 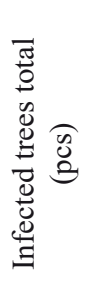 & 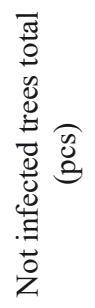 & 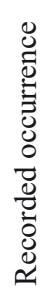 & 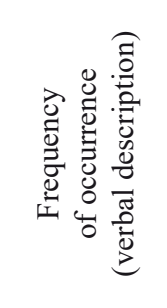 \\
\hline Juglans nigra & Juglandaceae & 1 & 34 & 61 & l & 40 & 60 & 1 & ample \\
\hline Laburnum alpinum & Fabaceae & & & & l & 1 & 1 & & \\
\hline Laburnum anagyroides & Fabaceae & & & & l & 1 & 12 & & \\
\hline Lonicera maackii & Caprifoliaceae & & & & l & 3 & 40 & & \\
\hline Maclura pomifera & Moraceae & l & 4 & 12 & & & & & \\
\hline Loranthus europaeus & Loranthaceae & & & & & & & / & seldom \\
\hline $\begin{array}{l}\text { Magnolia hypoleuca } \\
\times \text { tripetala }\end{array}$ & Magnoliaceae & l & 1 & 4 & / & 1 & 4 & & \\
\hline Malus dasyphylla & Rosaceae & & & & & & & l & strong \\
\hline Malus $\times$ atrosanguinea & Rosaceae & & & & l & 3 & 0 & & \\
\hline Malus domestica & Rosaceae & & & & l & 4 & 0 & $/ *$ & sporadic \\
\hline Malus $\times$ moerlandsii & Rosaceae & 1 & 1 & 22 & & & & & \\
\hline Malus niedzwetzkyana & Rosaceae & l & 1 & 0 & / & 1 & 0 & & \\
\hline Malus sp. & Rosaceae & & & & l & 29 & 28 & $/ *$ & scattered \\
\hline Photinia villosa & Rosaceae & & & & l & 2 & 6 & & \\
\hline Populus alba & Salicaceae & l & 3 & 19 & l & 2 & 33 & $/ *$ & seldom \\
\hline Populus balsamifera & Salicaceae & & & & & & & $/ *$ & sporadic \\
\hline Populus $\times$ canadensis & Salicaceae & & & & & & & $/ *$ & scattered \\
\hline Populus $\times$ canescens & Salicaceae & & & & l & 4 & 11 & / & fairly often \\
\hline Populus nigra & Salicaceae & & & & & & & l & ample \\
\hline Populus simonii & Salicaceae & & & & l & 3 & 2 & & \\
\hline Populus tremula & Salicaceae & & & & l & 4 & 25 & & \\
\hline Prunus padus & Rosaceae & 1 & 13 & 94 & l & 11 & 198 & & \\
\hline Prunus spinosa & Rosaceae & & & & 1 & 5 & 65 & & \\
\hline Prunus virginiana & Rosaceae & l & 6 & 13 & l & 3 & 46 & & \\
\hline Prunus sp. & Rosaceae & & & & l & 2 & 4 & & \\
\hline Quercus palustris & Fagaceae & l & 18 & 0 & l & 6 & 17 & & \\
\hline Quercus robur & Fagaceae & & & & l & 32 & 945 & & \\
\hline Robinia pseudoacacia & Fabaceae & / & 38 & 64 & / & 49 & 102 & l & scattered \\
\hline Salix $\times$ sepulcralis & Salicaceae & l & 8 & 4 & l & 8 & 7 & & \\
\hline Salix alba & Salicaceae & l & 1 & 30 & l & 10 & 39 & 1 & fairly often \\
\hline Salix fragilis & Salicaceae & & & & l & 1 & 1 & $/ *$ & fairly often \\
\hline Salix pentadra & Salicaceae & & & & l & 1 & 0 & & \\
\hline Salix $\times$ rubens & Salicaceae & & & & & & & l & often \\
\hline Sorbus aucuparia & Rosaceae & & & & l & 1 & 2 & & \\
\hline Syringa $\times$ chinensis & Oleaceae & & & & l & 1 & 8 & & \\
\hline Syringa reticulata & Oleaceae & & & & l & 3 & 20 & & \\
\hline Syringa villosa & Oleaceae & & & & l & 1 & 1 & & \\
\hline Swida sanguinea & Cornaceae & & & & l & 1 & 244 & & \\
\hline Tilia americana & Tiliaceae & 1 & 1 & 4 & I & 2 & 1 & 1 & fairly strong \\
\hline
\end{tabular}


Table 1 continued.

\begin{tabular}{|c|c|c|c|c|c|c|c|c|c|}
\hline \multicolumn{2}{|l|}{ Research } & \multicolumn{3}{|c|}{$\begin{array}{c}\text { Bulír (2016) } \\
\text { - this experiment }{ }^{1}\end{array}$} & \multicolumn{3}{|c|}{ Spálavský (2001) 2} & \multicolumn{2}{|c|}{ Unar et al. $(1985)^{2}$} \\
\hline $\begin{array}{l}n \\
0 \\
0 \\
0 \\
0 \\
0 \\
2 \\
0 \\
0 \\
0 \\
3 \\
0 \\
0 \\
0\end{array}$ & 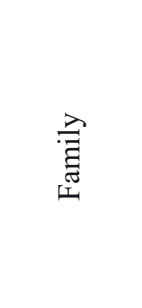 & 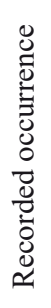 & 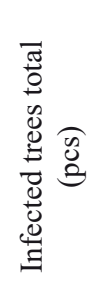 & 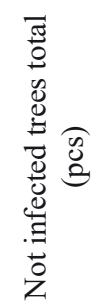 & 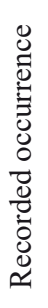 & 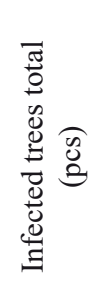 & 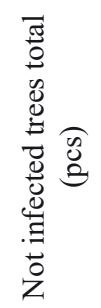 & 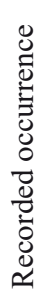 & 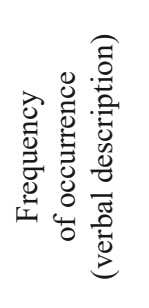 \\
\hline Tilia cordata & Tiliaceae & 1 & 189 & 301 & 1 & 286 & 249 & 1 & ample \\
\hline Tilia $\times$ vulgaris & Tiliaceae & I & 19 & 13 & l & 12 & 21 & & \\
\hline Tilia euchlora & Tiliaceae & l & 2 & 4 & / & 1 & 3 & $/ *$ & scattered \\
\hline Tilia platyphyllos & Tiliaceae & l & 162 & 259 & I & 102 & 367 & $/ *$ & often \\
\hline Tilia tomentosa & Tiliaceae & l & 11 & 17 & / & 10 & 11 & l & ample \\
\hline Tilia petiolaris & Tiliaceae & / & 8 & 14 & / & 12 & 23 & & \\
\hline Ulmus laevis & Ulmaceae & l & 56 & 145 & & & & & \\
\hline Ulmus minor & Ulmaceae & I & 26 & 156 & & & & & \\
\hline Sum total (pcs) & & & 1,362 & 3,085 & & 1,430 & 5,354 & & \\
\hline
\end{tabular}

${ }^{1}$ chateau park, ${ }^{2}$ Lednice cadastral area, / infection recorded within the chateau park, $/ *$ infection recorded only outside the borders of the chateau park

the mentioned taxa varies between $29.87 \%$ (Acer campestre) and $40.88 \%$ (Acer platanoides), with the average of $34.28 \%$ of their total number - in a sample of 2,672 specimens potentially prone to infection (Šimek et al. 2009) this corresponds to 916 infected trees and shrubs. From Table 2, it is evident that the $1^{\text {st }}$ infection degree is the most frequent (24.02\% on average). By contrast, critical occurrence of mistletoe ( $3^{\text {rd }}$ degree) in the group of the seven compared species is the lowest $(3.71 \%$ on average). This fact is essential for appropriate tree maintenance (mainly the extent of pruning) and also for the related economy of care in the historical garden. The highest share of $3^{\text {rd }}$ degree infection is currently held by Tilia cordata, which is the most challenged species as regards both life expectancy and the ability to fulfil its functions in the park composition. Of particular interest in this respect is a comparison with related Tilia platyphyllos - under similar conditions and within a numerically comparable sample of specimens. This taxon is colonised by mistletoe with a similar probability, but according to the prevailing degree of infection, the occurrence of mistletoe over time can be characterized as insignificant. At the same time, the values presented in Table 2 are compared with known numbers of specimens in a given taxon (Pejchal and Šimek 1996), and this clearly shows

Table 2. Overview of the extent and degree of mistletoe infection in the most significant host woody species

\begin{tabular}{|c|c|c|c|c|c|c|c|c|c|c|}
\hline \multirow{3}{*}{$\begin{array}{l}\text { Year } \\
\text { Mistletoe occurrence } \\
\text { Host woody species }\end{array}$} & \multirow{2}{*}{$\begin{array}{c}1996^{1} \\
0-3 \\
\end{array}$} & \multicolumn{9}{|c|}{$2016^{2}$} \\
\hline & & \multicolumn{2}{|c|}{0} & \multicolumn{2}{|c|}{1} & \multicolumn{2}{|c|}{2} & \multicolumn{2}{|c|}{3} & \multirow{2}{*}{$\begin{array}{c}0-3 \\
\Sigma\end{array}$} \\
\hline & $\Sigma$ & $\Sigma$ & $\%$ & $\Sigma$ & $\%$ & $\Sigma$ & $\%$ & $\Sigma$ & $\%$ & \\
\hline Acer campestre & 1,315 & 850 & 70.13 & 267 & 22.03 & 69 & 5.69 & 26 & 2.15 & 1,212 \\
\hline Acer platanoides & 168 & 94 & 59.12 & 44 & 27.67 & 16 & 10.06 & 5 & 3.14 & 159 \\
\hline Acer pseudoplatanus & 201 & 128 & 67.37 & 49 & 25.79 & 9 & 4.74 & 4 & 2.11 & 190 \\
\hline Crataegus monogyna & 107 & 60 & 61.22 & 21 & 21.43 & 13 & 13.27 & 4 & 4.08 & 98 \\
\hline Robinia pseudoacacia & 130 & 64 & 62.75 & 29 & 28.43 & 7 & 6.86 & 2 & 1.96 & 102 \\
\hline Tilia cordata & 552 & 301 & 61.43 & 92 & 18.78 & 40 & 8.16 & 57 & 11.63 & 490 \\
\hline Tilia platyphyllos & 501 & 259 & 61.52 & 140 & 33.25 & 21 & 4.99 & 1 & 0.24 & 421 \\
\hline Total & 2,974 & 1,756 & 65.72 & 642 & 24.02 & 175 & 6.56 & 99 & 3.71 & 2,672 \\
\hline
\end{tabular}

${ }^{1}$ Pejchal and Šimek, ${ }^{2}$ Bulír; mistletoe occurrence: 0 - no occurrence, 1 - insignificant occurrence, 2 - significant occurrence, 3 - critical occurrence 
a decrease in host trees and shrubs, caused precisely by the significant pathogenic activity of mistletoe. The expansion of mistletoe in the locality of Lednice has been definitely supported by broadly suitable environmental conditions corresponding to the data further specified by, among others, Zuber (2004) and Mathiasen et al. (2008). It is in particular influenced by high average annual temperature and its favourable distribution during the year, by sufficient humidity available to host trees and shrubs throughout the year, and finally by the presence of numerous birds dispersing the seeds, such as the Mistle Thrush (Turdus viscivorus), the Fieldfare (Turdus pilaris), the Bohemian Waxwing (Bombycilla garrulus) and the Great Tit (Parus major). Moreover, an especially important factor influencing the local growth of mistletoe is undoubtedly the abundance of solitary trees, fully exposed to the sun, or of small groups or lines of trees. Favourable conditions for the growth of mistletoe are further enhanced by the presence of an unusual and taxonomically rich spectrum of 356 broad-leaved trees and shrubs potentially prone to infection (Pacáková-Hošt’álková et al. 1999). The above facts correspond well to the results of our research, which aimed to find out, among others, the aggregate quantitative extent of infection of the trees and shrubs growing in the chateau park. Based on Table 1, out of the total number of 7,123 broadleaved trees reported in 2009 (Šimek et al. 2009) and 2016 (62.65\% of all trees), a total of 5,038 trees can be included among the potential host plants, i.e. $44.3 \%$ of all the trees and shrubs growing in the chateau park. The presence of mistletoe was demonstrably detected in 1,362 specimens, i.e. in almost $12 \%$ of the trees and shrubs present in the area, with 916 of the infected specimens $(8 \%)$ belonging to the seven most significant host woody species (Tab. 2). The presence and impact of mistletoe on trees and shrubs have been observed in the composition of the park for many years. Several negative phenomena have been simultaneously observed in the qualitative (aesthetic and biological) parameters of the trees and shrubs, which are fundamental not only in relation to the care of such trees and shrubs, but also in relation to the conservation or renewal of the listed chateau park composition. Therefore, the research also analysed mistletoe occurrence and the degree of infection of the host tree or shrub in relation to individual development stages (DS) of woody plants (Pejchal 2008). A summary table (Tab. 3) documents the changes in the extent and degree of mistletoe infection between 1996 and 2016 in relation to the recorded development stages for the seven most significant host woody species. The parameter of development stage is probably the best one to reflect not only the distribution of mistletoe plants on individual host woody taxa, but also the overall biological and compositional potential of the trees and shrubs (Pejchal 2008). The comparison of new and previous available DS data (Pejchal and Šimek 1996) shows a progressive and striking decrease in the number of trees not yet infected by mistletoe (code 0 ), by a total of $10.3 \%$ over the past 20 years, which in absolute terms

Table 3. Changes over time in the extent and degree of infection of trees and shrubs by mistletoe in relation to their development stage (DS)

\begin{tabular}{|c|c|c|c|c|c|c|c|c|c|c|c|c|}
\hline $\begin{array}{l}\text { Mistletoe } \\
\text { occurrence }\end{array}$ & & 0 & & & 1 & & & 2 & & & 3 & \\
\hline Year & 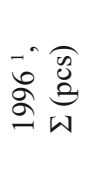 & 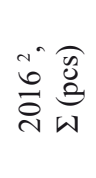 & 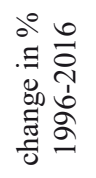 & 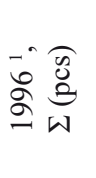 & 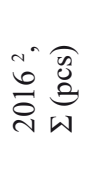 & 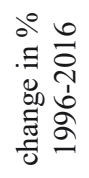 & 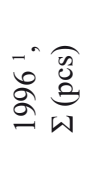 & 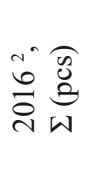 & 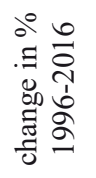 & 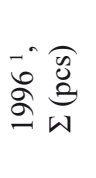 & 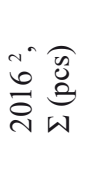 & 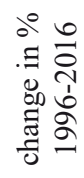 \\
\hline DS 1 & 16 & 2 & -87.5 & 0 & 1 & 100 & 0 & 0 & 0 & 0 & 0 & 0 \\
\hline DS 2 & 94 & 81 & -13.8 & 17 & 22 & 29.4 & 12 & 1 & -91.7 & 0 & 0 & 0 \\
\hline DS 3 & 783 & 702 & -10.4 & 138 & 177 & 28.3 & 31 & 7 & -77.4 & 4 & 1 & -75 \\
\hline DS 4 & 978 & 893 & -8.7 & 203 & 284 & 39.9 & 97 & 59 & -39.2 & 93 & 31 & -66.7 \\
\hline DS 5 & 245 & 220 & -10.2 & 74 & 91 & 23 & 103 & 61 & -40.8 & 86 & 39 & -54.7 \\
\hline Total & 2,116 & 1,898 & -10.3 & 432 & 575 & 33.1 & 243 & 128 & -47.3 & 183 & 71 & -61.2 \\
\hline
\end{tabular}

For the most significant host woody species in Table 2.

${ }^{1}$ Pejchal and Šimek, ${ }^{2}$ Bulíŕ; mistletoe occurrence: 0 - no occurrence, 1 - insignificant occurrence, 2 - significant occurrence, 3 - critical occurrence; development stage: DS 1 - newly planted/germinating specimen, DS 2 - rooted specimen, DS 3 - stabilized maturing specimen, DS 4 - mature specimen, DS 5 - superannuated specimen 
represents a decline from 2,116 to 1,898 trees. The loss structure across the individual development stages is surprisingly balanced, with almost identical percentage values for DS 3 and DS 5 (10.4\% and $10.2 \%$ decrease, respectively). The loss of trees in DS 4 reached $8.7 \%$. On the other hand, in the same period, there was a $33.1 \%$ increase in the total number of trees insignificantly infected by mistletoe ( $1^{\text {st }}$ degree), which was reported for all development stages. While in 1996 this degree of infection was observed in 432 specimens in absolute terms, in 2016 this number rose to as many as 575 specimens. The number of infected specimens increased most significantly in DS 4 (by 39.9\%), from 203 to 284 specimens, followed by DS 3 (by $28.3 \%$ ), from 138 to 177 specimens. The total number of significantly infected specimens ( $2^{\text {nd }}$ degree) decreased especially in DS 4 (by 39.18\%), from 97 to 59 specimens, and in DS 5 (by $40.78 \%$ ). An analogous development process was also observed in critically infected trees ( $3^{\text {rd }}$ degree), where the number of specimens in DS 4 and DS 5 decreased by as much as $66.7 \%$ and $54.7 \%$, respectively. In this category, the highest change was in the total $(61.2 \%$ decrease $)$. The current distribution of development stages (DS) and infection intensity of all the trees and shrubs is shown in Figure 2. The minimum number of trees in DS 1 and DS 2 suggests that the probability of colonization of host woody trees by mistletoe grows with age. The number of non-infected stabilized maturing specimens (DS 3) accounts for 79.14\% of their total number; in the case of mature specimens (DS 4) it is approximately $70.48 \%$, while in the case of superannuated specimens (DS 5) their share is only $53.53 \%$. The recorded infection intensity differs quantitatively across the individual development stages and host taxa. The situation is relatively balanced in the case of $1^{\text {st }}$ infection degree, where different development stages of trees are colonised almost evenly (DS $3-19.95 \%$, DS 4 - $22.42 \%$ and DS $5-22.14 \%$ ). More advanced stages of colonisation of host plants, marked as $2^{\text {nd }}$ infection degree and $3^{\text {rd }}$ infection degree, are found mainly in development stages DS 4 and DS 5, where the sum of infected specimens reaches $14.84 \%$ and $9.49 \%$, respectively. All in all, there is an evident downward trend in the number of colonised specimens accompanying a proportional increase in the intensity of their infection. However, in comparison with the standard natural development of trees and shrubs infected by mistletoe, in our locality this phenomenon is once again influenced and to a certain extent distorted, because distinctly damaged trees and shrubs have been removed in the context of ongoing cultivation measures. These often concerned significantly infected specimens $\left(2^{\text {nd }}\right.$ infection degree), and even more often critically infected specimens $\left(3^{\text {rd }}\right.$ infection degree). Between 1996 and 2016, within

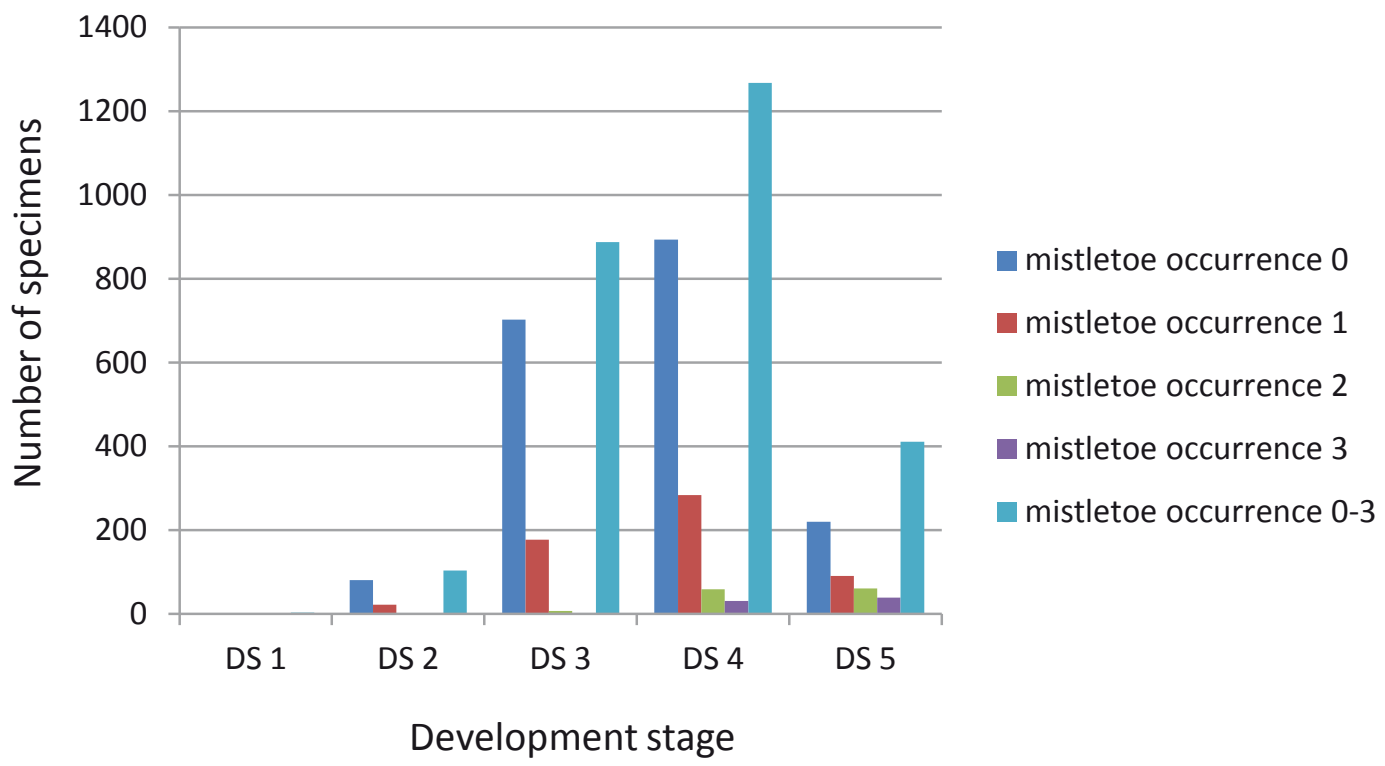

Mistletoe occurrence: 0 - no occurrence, 1 - insignificant occurrence, 2 - significant occurrence, 3 - critical occurrence; development stage: DS 1 - newly planted/germinating specimen, DS 2 - rooted specimen, DS 3 - stabilized maturing specimen, DS 4 - mature specimen, DS 5 - superannuated specimen

Figure 2. Comparison of the actual structure of the development stages of all host woody species and the extent of their infection (year 2016) 
the chateau park area a total of 302 specimens of mistletoe infected trees (only among the seven most frequent host woody species) died, or rather had to be removed for safety, health and aesthetical reasons. A more detailed structure of these data is to be found in Table 2 .

The fact that the intensity of colonisation increases with the age of host woody species is most likely related to their decreasing vitality (Pejchal 2008) and is linked with the changes that take place in the architecture of their crowns, especially with crown thinning and degeneration. The intensity of colonisation is further modified by taxonomyspecific characteristics of the host species, by their location and by the environmental conditions of the habitat. All of the above findings thus clearly quantify the intensity and extent of mistletoe occurrence and suggest its development over time, including the qualitative consequences of its impact on the spectrum of significant host trees and shrubs. In the given locality, the consequences of mistletoe pathogenic activity are no doubt significant and they need to be given adequate attention. When looking for suitable solutions, in particular cultivation measures, they need to be considered together with the role of other pathogenic factors and environmental conditions, and also in relation to other environmental functions of these woody plants, as Watson (2001) and Mathiasen et al. (2008) note.

\section{CONCLUSIONS}

The research shows that during the selected time period, i.e. between 1985 and 2016, there were significant changes not only in the number of observed host trees and shrubs, but also in the extent of infection of individual hosts. More specifically, the following facts were observed:

1. The spectrum of host trees and shrubs described in the same area has changed noticeably over the last 31 years; as at 2016, it taxonomically includes 13 families $(+3), 19$ genera $(+5)$ and a total of 42 species $(+18)$, despite the fact that the number of taxa grown in the chateau park has not changed significantly since 1985 . Parasitisation by mistletoe was recorded also in Aesculus $\times$ marylandica, Fraxinus biltmoreana, Magnolia hypoleuca $\times$ tripetala and Malus $\times$ moerlandsii - species which are not included in the most extensive list of host species published (Barney 1998). The largest amount of species and specimens with mistletoe occurrence was recorded in 2001, before the extensive renewal measures (mainly felling of the hazardous individuals) performed in the park in the last five years;

2. A considerable change was observed in the frequency and degree of infection in the individual host species. The species in the chateau park which were not infected in the past, such as Acer campestre, Crataegus monogyna and Tilia platyphyllos, belong today to the group of the most frequently infected host trees and shrubs. On the other hand, the taxa that were often colonised by mistletoe in the past, such as representatives of the Salix, Populus or Malus genera, have become less significant for its occurrence. In Acer negundo, Aesculus hippocastanum, Fraxinus americana, and Fraxinus angustifolia, the occurrence of mistletoe was not detected any more. On the other hand, a stable occurrence of mistletoe over time was observed in the specimens of Acer platanoides, Acer pseudoplatanus, Celtis occidentalis and Juglans nigra, which are infected relatively often, even extensively;

3. Currently, the most heavily and most frequently infected woody species in the chateau park include, in particular, Acer campestre, Acer platanoides, Acer pseudoplatanus, Crataegus monogyna, Robinia pseudoacacia, Tilia cordata and Tilia platyphyllos. The share of infected specimens of these hosts amounts on average to $34.28 \%$ of their total number.

This information has key importance for choosing an appropriate and balanced management approach in the systems of care for heritage gardens, including solutions for complex renewal measures in the areas with naturally higher and high occurrence of mistletoe. It can, for instance, help with selecting appropriate substitute species less prone to mistletoe colonization. These data can also serve as a basis for a new approach to tree growing and maintenance. In particular, they can help modify the way trees are pruned. From the biological point of view the data provide us with, among other things, information for further studies of mistletoe occurrence and its pathogenic role on host woody species, not only in the Czech Republic.

\section{FUNDING}

This paper was created with the support for project No. DF11P01OVV019 - Methods and tools of landscape architecture for spatial development 
- which fulfils the thematic priority 1.4. of the Programme of Applied Research and Development of the National and Cultural Identity, financed by the Ministry of Culture of the Czech Republic.

\section{CONFLICT OF INTEREST}

Authors declare no conflict of interest.

\section{REFERENCES}

Ball P.W., 1993. Viscum L. In: Flora Europaea. Vol. 1. Psilotaceae to Platanaceae. T.G. Tutin, N.A. Burges, A.O. Chater (eds.), Cambridge University Press, Cambridge: 86 .

BARBU C., 2010. The incidence and distribution of white mistletoe (Viscum album ssp. abietis) on Silver fir (Abies alba Mill.) stands from Eastern Carpathians. Ann. For. Res. 53: 27-36.

Barney C.W., HawksworthF.G., GeILs B.W., 1998. Host of Viscum album. Eur. J. For. Path. 28: 187-208.

BöHlingN.,GreuterW.,RausT.,SNOGerupB.,SNOGERUP S., Zuber D., 2002. Notes on the Cretan mistletoe, Viscum album subsp. creticum (Loranthaceae/ Viscaceae). Israel J. Plant. Sci. 50: 77-84.

Bulíř P., 2010. Analýza výskytu jmelí bílého (Viscum album L. ssp. album) a zdravotní stav dřevin $\mathrm{v}$ zámeckém parku Lednice [Analysis of European mistletoe (Viscum album L. ssp. album) occurrence and health condition of trees and shrubs in the Lednice castle park]. In: Vliv abiotických a biotických stresorů na vlastnosti rostlin 2010. L. Bláha (eds.), VÚRV Praha a ČZÚ v Praze, Praha, Czech Republic: 160-163.

Butin H., 1995. Tree Diseases and Disorders. Oxford University Press, New York, USA.

Der J.P., Nickrent D.L., 2008. A molecular phylogeny of Santalaceae (Santalales). Syst. Bot. 1(33): 107-116.

Culek M., 1996. Biogeografické členění České republiky [Biogeographical Division of the Czech Republic]. Enigma, Praha, Czech Republic.

ELIÁŠ P., 2010. Imelo v urbánnej vegetách Slovenska a možnosti ochrany drevín v mestách [Mistletoe in urban vegetation in Slovakia and the possibilities of protection of trees and shrubs in cities]. Proc. Dreviny vo verejnej zeleni 2010, 22-23 June, SAV, Zvolen, Slovakia: 35-39.

Hawksworth F.G., Scharpf R.F., Marosy M., 1991. European mistletoe continues to spread in Sonoma County. California Agriculture 6(45): 39-40.

Hegi G., 1981. Illustrierte Flora von Mitteleuropa Vol. 3/1 [Illustrated flora of Central Europe Vol. 3/1]. P. Parey, Berlin, Germany.

HoufeK J., 1973. Rozšíření jmelí (Viscum L.) v Československu [Distribution of mistletoe (Viscum L.) in Czechoslovakia]. Zprávy Čs. Bot. Společnosti 8: $210-214$.

Huber J., 2011. The case of the insidious interceptor. Arborist News 5(20): 46-47.
KoBLÍŽEK J., 2000. Jehličnaté a listnaté dřeviny našich zahrad a parků I. [Coniferous and broad-leaved trees and shrubs of our gardens and parks I.]. Sursum, Tišnov, Czech Republic.

KoŁodziejek J., Patykowski J., Kolodziejek R., 2013. Distribution, frequency and host patterns of European mistletoe (Viscum album subsp. album) in the major city of Lodz, Poland. Biologia 68(1): 5564.

KubátK.,Hrouda L., ChrtekJ., KaplanZ., Kirschner J., ŠTĚPÁneK J., 2002. Klíč ke Květeně České republiky [Key to the Flora of the Czech Republic]. Academia, Praha, Czech Republic.

Luther P., Becker H., 1987. Die Mistel - Botanik, Lektine, medizinische Anwendung [The Mistletoe - Botany, Lectins, Medical Application]. Springer, Berlin, Germany.

Mathiasen R.L., Nickrent D.L., Shaw D.C., Watson D.M., 2008. Mistletoes - pathology, systematics, ecology and management. Plant Disease 7(92): 9881006.

Nickrent D.L., Malécot V., Vidal-Russell R., DeR J.R., 2010. A revised classification of Santalales. Taxon 59: 538-558.

PacÁkovÁ-HošŤÁlková B., Petrư J., Riedl D., SvobodA A.M., 1999. Zahrady a parky v Čechách na Moravě a ve Slezku [Gardens and Parks in Bohemia, Moravia and Silesia]. Libri, Praha, Czech Republic.

Pejchal M., Šimek P., 1996. Vyhodnocení dendrologického potenciálu $\mathrm{v}$ zámeckém parku v Lednici - projekt [Evaluation of dendrological potential in the Lednice castle park - project]. Zahradnická fakulta, Mendelova univerzita, Lednice.

Pejchal M., 2008. Arboristika I. Obecná dendrologie [Arboristics I - General Dendrology]. SZaŠ a VOŠZa Mělník, Mělník, Czech Republic.

ProcházKa F., 2004. A centre of occurrence of Viscum album subsp. album in eastern Bohemia and an overview of the diversity of its host plants in the Czech Republic. Preslia 76: 349-359.

Rist L., Shannker R.U., Ghazoul J., 2011. The spatial distribution of mistletoe in Southern Indian tropical forest et multiple scales. Biotropica 43(1): 50-57.

Roloff A., BÄrtels A., 2006. Flora der Gehölze [Flora of Woody Plants]. Eugen Ulmer, Stuttgart, Germany.

SKALICKÝ V., 1988. Regionálně fytogeografické členění [Regional-phytogeographical division]. In: S. Hejný and B. Slavík (ed.), Květena ČSR 1[Flora of the Czech Socialist Republic 1]. Academia, Praha, Czech Republic: 103-121.

SLAvík B., 1988. Regionálně fytogeografické členění [Regional-phytogeographical division]. In: S. Hejný and B. Slavík (ed.), Květena ČSR 1 - mapa. [Flora of the Czech Socialist Republic 1 - map supplement]. Academia, Praha, Czech Republic. 
SLAvík B., 1997. Květena České republiky - 5 [Flora of the Czech Republic - 5]. Academia, Praha, Czech Republic.

SPÁlAVSKÝ M., 2001. Zhodnocení rodu Viscum L. z pohledu zahradní a krajinářské tvorby [Evaluation of genus Viscum $L$. from the point of view of landscape architecture]. Thesis, Zahradnická fakulta, Mendelova univerzita, Lednice, Czech Republic, 95 p.

Stopp F., 1961. Unsere Misteln [Our Mistletoe]. A. Ziemsen, Wittenberg-Lutherstadt, Germany.

ŚwiĘS F., 2008. Materials for the distribution and ecology of the mistletoe (Viscum album L. subsp. album P. W. Ball.) in central-eastern Poland. VII Vicinity of Urzędów. Ann. UMCS 63: 51-65.

Šmek P., Pejchal M., Kučera P., Krejčiřík P., Bulír P., Richter M., 2009. Projekt regenerace a obnovy vegetačních prvků v zámeckém parku v Lednici - project [Project of regeneration and renewal of vegetation elements in the Lednice castle park project]. Zahradnická fakulta, Mendelova univerzita, Lednice.

Tsopelas P., 2004. Mistletoe (Viscum album) in the fir forest of Mount Parnis, Greece. For. Ecol. Manage. 202: 59-65.

UNAR J., 1985. Příspěvek k rozšíření jmelí bílého (Viscum album L.) na Moravě [Paper on the distribution of
European mistletoe (Viscum album L.) in Moravia]. Zpr. Čs. Bot. Společnosti 20: 115-127.

Varga I., PoczaiP., Tiborcz V., Aranyi N.R., BaltazÁr T., Bartha D., Pejchal M., Hyvönen J., 2014. Changes in the distribution of European mistletoe (Viscum album) in Hungary during the last hundred years. Folia Geobot. 49(4): 559-577.

WANGERIN W., 1937. Gattung Viscum L. [Genus Viscum L.]. In: Lebensgeschichte der Blütenpflanzen Mitteleuropeas Vol. 2/1. W. Wangerin and C. Schröter (eds.), Ulmer, Stuttgart, Germany: 9721146.

Watson D. M., 2001. Mistletoe - A keystone resource in forests and woodlands worldwide. Annu. Rev. Ecol. System. 32: 219-249.

ZachwatowiczM.,PetrovićK., WóJcikowska-SudniK B., 2008. The occurrence of European mistletoe under the conditions of high human impact in the central part of Warsaw, Poland. In: Problemy Ekologii Krajobrazu XXII. Warsaw University, Warsaw, Poland: 101-114.

Zuber D., 2004. Biological flora of Central Europe: Viscum album L. Flora 199: 181-203.

Received February 4, 2017; accepted June 7, 2017 